\title{
準天頂衛星システムにおける衛星故障時の隣接衛星再配置*1 Relocation of Satellites Adjacent to a Failed Satellite for the Quasi-Zenith Satellite System
}

\author{
坂 井 丈 泰*2 \\ Takeyasu SAKAI
}

Key Words : QZSS, Satellite Navigation, Satellite Relocation, Navigation

\begin{abstract}
The Quasi-Zenith Satellite System (QZSS) has been developed by Japan as a regional navigation satellite system covering Japanese territory and the surrounding region. The most distinguished property of the QZSS is broadcast of radiosignals from a high elevation angle to users, which improves availability of position fixes even in urban canyons and mountainous area. It is, however, a potential problem that a fail of QZSS satellite degrades this property largely because the QZSS consists of the relatively small number of satellites. The author investigated a recovery method from such a situation by relocation of satellites adjacent to the failed satellite. According to the computational results for the constellations of three to five satellites, the minimum elevation angle of the system could be improved by the relocation by about 20 degrees with change of orbital planes and by 6 to 10 degrees even if orbital planes are not changed.
\end{abstract}

\section{1. 緒言}

米国の GPS をはじめとする衛星測位システムが各国で

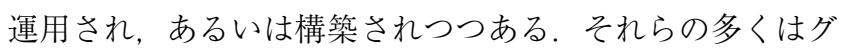
ローバルなサービスエリアをもつものであるが, 我が国は 対象地域を限定して測位サービスを提供する準天頂衛星シ ステム（QZSS：quasi-zenith satellite system）の開発を 進めている。準天頂衛星システムの特長の一つはユーザに 対する衛星の仰角を高くできることで, 都市部や山間部に 対しても天頂方向から測位信号を放送し, 有効な測位サー ビスを提供できる ${ }^{1,2)}$. 準天頂衛星システムの初号機QZS-1 (愛称「みちびき」) は 2010 年 9 月 11 日に宇宙航空研究 開発機構（JAXA）種子島宇宙センターから打ち上げられ, 現在は関係機関による各種の実証実験が実施されている33.

準天頂衛星システムは地域を限定する代わりに少数の衛 星により測位サービスを実現するものであるから, 故障等 により衛星が停止した場合はシステム性能に対する影響が 相対的に大きい. この問題に対処するため, 本研究では, 準 天頂衛星の故障時に隣接衛星を再配置することによりシス テム性能を一定程度回復させる手法を検討した。この結果 として, 隣接衛星の再配置によるシステム性能の回復措置 は可能であり, 回復の程度には軌道面制御の有無により差 がみられることを報告する。

\section{2. 準天頂衛星システム}

2.1 準天頂衛星の軌道 準天頂衛星システムの大きな特 徵は, 地上軌跡が 8 の字となる傾斜地球同期軌道 (IGSO :

\footnotetext{
*1 (C) 2012 日本航空宇宙学会

平成 24 年 4 月 17 日原稿受付

*2 独立行政法人電子航法研究所航法システム領域
}

inclined geosynchronous orbit）を用いていることである. これは地球同期軌道の一種であるから軌道長半径は静止衛 星と同じ $42164 \mathrm{~km}$ で, 軌道傾斜角をもつため衛星が南北 に移動する。この軌道は地域を限定して高仰角から通信・ 測位サービスを提供するのに適しているとされ4), 企画段 階の GPS でも検討されたことがあった5). 静止衛星と異な り地上に 8 の字を描くように移動するが，地上局を低緯度 地域に配置すれば 1 局だけでも通信リンクを常時保つこと ができる。

地上に同一の 8 の字を描くように複数の衛星を配置すれ ば，それらの衛星がサービスエリアの上空を順に巡回する こととなる. 準天頂衛星システムの基本的なコンセプトは, このような衛星を合計で 3 機程度配置すれば, 常時そのう ちの少なくとも 1 機が日本上空に到来しており, 常に高仰 角から信号を提供することが可能になるというものである. 実際の準天頂衛星システムでは離心率をもたせて楕円軌道 としており，遠地点を北端にすることで日本上空における 滞在時間を長くするよう工夫されている.

衛星測位サービスでは最低でも 3 機（水平方向の測位に 限る場合）ないしは 4 機（高度も含めて 3 次元の測位を行 う場合）の測位衛星を幾何学的に離れた位置関係になるよ う配置する必要がある。ただしすべての衛星が高仰角にあ る必要はないわけで, 同一の 8 の字を描く衛星群により衛 星測位を実現できる。必要に応じて, 異なる 8 の字を描く 衛星や周回衛星, あるいは静止衛星を組み合わせてもよい. 実際に準天頂衛星システムでは, 同一の 8 の字を描く軌道 に3〜4機を配置し，これに $3 \sim 4$ 機の静止衛星を組み合わ せる案が検討されている. 中国が開発中の COMPASS や インドの IRNSS も, 同様の構成により衛星測位システム を構築しようとしている6 8). 
2.2 放送信号 準天頂衛星システムは, 測位サービスを 提供するため, （i）GPS の信号と類似した測位信号（QZS$\mathrm{L} 1 \mathrm{C} / \mathrm{A}$ 等, 3 周波数 4 波), (ii) GPS 補強システムの国際 標準規格であるSBAS (satellite-based augmentation system) ${ }^{9 \sim 11)}$ に類似した補強信号 (QZS-L1SAIF), (iii) 独自 の補強信号 (QZS-LEX), の 3 種類の測位信号を放送する. （i）及び（ii）はそれぞれ対応する GPS 信号や SBAS 信号 と可能な限り同一の仕様とされているが，拡散符号 (PRN コード）を変えてあるため既存の GPS/SBAS 受信機は受 信しない

準天頂衛星システムの（i）（iii）のいずれの信号も距離を 測定する機能を有しており, 測位信号として利用できる（信 号により性能の違いはある)。準天頂衛星システムは GPS と完全な相互運用性をもち, 両者の測位衛星を併用するこ とでより良い性能を得ることができる。

（ii）及び（iii）の補強信号は，測位信号としての機能を もつと同時に，ユーザに対して補強情報を提供する。これ にはたとえば GPS 衛星に対するディファレンシャル補正 情報が含まれており，ユーザは補強情報を適用することで 測位精度を改善できる。補強対象のすべての測位衛星の補 強情報が一つの補強信号に乗せられているから，ユーザは いずれか 1 機の衛星から補強信号を受信すれば十分である.

準天頂衛星システムが採用している軌道や放送している 測位信号の詳細は，ユーザインターフェース仕様書を参照 されたい12).

\section{3. 衛星故障時の性能}

準天頂衛星システムは一般ユーザに対してサービスを提 供する実用システムであり，通常時のみならず故障等のた め衛星が停止する場合についても一定の性能が維持される ことが望ましい，ところが，準天頂衛星システムは少数の 測位衛星により地域限定の測位サービスを実現するもので あり，衛星が停止した場合はシステム性能に対する影響が 相対的に大きい. この問題について検討するため, まず衛 星停止時の性能を調べることとした

現在は多数の GPS 衛星が運用されていることから，上 空が開けた場所では GPS 衛星が不足することは少ない。衛 星数が不足しがちなのは周囲に障害物の多い都市部や山岳 地帯であって，このような環境では天頂付近に準天頂衛星 があると有効に機能する。また，準天頂衛星システムが提 供する補強情報を確実に受信するには，これもなるべく仰 角の高い位置から放送されていることが望ましい。こうし た準天頂衛星システムの利用状況に鑑み, 本研究において は，ある時点にユーザが利用可能な複数の準天頂衛星のう ちのもっとも高い仰角をシステム仰角と定義し, その最低 值を指標としてシステム性能を評価することとする。また, 衛星の停止は 1 機までを想定する.

評価に使用した軌道パラメー夕は第 1 表のとおりで，い ずれも準天頂衛星システムユーザインターフェース仕様書 に準じて設定した ${ }^{12)}$ 。軌道傾斜角 43 度，離心率 0.075 の 楕円軌道で，実際に QZS-1 衛星も同様の軌道を周回してい
第 1 表 準天頂衛星の軌道パラメータ

\begin{tabular}{|c|c|}
\hline 項 目 & 設 定 值 \\
\hline 軌道長半径 & $42164.16945 \mathrm{~km}$ \\
\hline 離心率 & 0.075 \\
\hline 軌道傾斜角 & $43.0 \mathrm{deg}$ \\
\hline 近地点引数 & $270 \mathrm{deg}$ \\
\hline 地上軌跡の中心経度 & 東経 $135 \mathrm{deg}$ \\
\hline 昇交点赤経 & $\Omega_{0}-\{0,120,240\} \operatorname{deg}$ (3 衛星) \\
\hline \multirow{5}{*}{ 平均近点角 } & $\Omega_{0}-\{0,90,180,270\} \operatorname{deg}$ (4 衛星) \\
\hline & $\Omega_{0}-\{0,72,144,216,288\} \operatorname{deg}$ (5 衛星) \\
\hline & $M_{0}+\{0,120,240\} \operatorname{deg}(3$ 衛星） \\
\hline & $M_{0}+\{0,90,180,270\} \operatorname{deg}(4$ 衛星） \\
\hline & $M_{0}+\{0,72,144,216,288\} \operatorname{deg}$ ( 5 衛星) \\
\hline
\end{tabular}

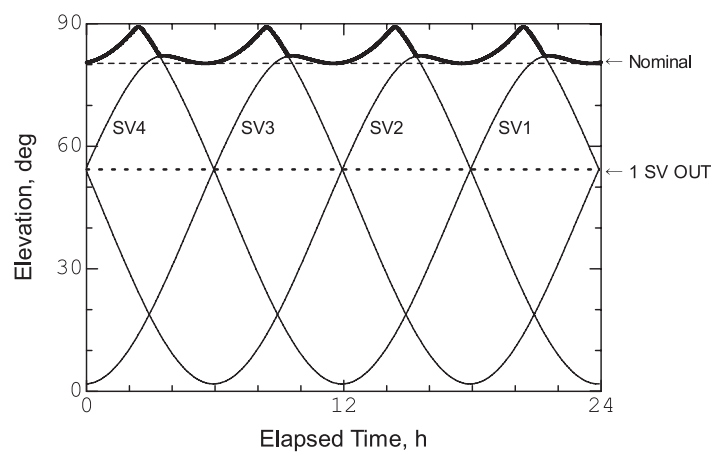

第 1 図 準天頂衛星の仰角の変化

\begin{tabular}{ccccc}
\multirow{2}{*}{ 第 2 表 } & \multicolumn{3}{c}{ 準天頂衛星の最低仰角 (単位 $[\mathrm{deg}]$} \\
\hline 準天頂 & 停止 & \multicolumn{3}{c}{ ユーザ位置 } \\
\cline { 3 - 5 } 衛星数 & 衛星数 & 東京 & 稚内 & 那覇 \\
\hline 3 & 0 & 75.9 & 64.6 & 69.1 \\
& 1 & 29.9 & 19.7 & 39.5 \\
\hline \multirow{2}{*}{4} & 0 & 80.3 & 72.8 & 69.1 \\
& 1 & 54.3 & 43.4 & 64.1 \\
\hline 5 & 0 & 80.3 & 76.6 & 76.2 \\
& 1 & 68.1 & 56.8 & 69.6 \\
\hline
\end{tabular}

る. 準天頂衛星システムを構成する衛星数は $3 \sim 5$ 機とし て, 同一の 8 の字に均等に配置する. 各衛星の区別が必要 な場合は，平均近点角の昇順に番号を付して SV1〜 5 のよ うに表すこととする。

4 衛星を配置した場合を例として，東京における各衛星 の仰角の変化を第 1 図に示す。各衛星とも，北上に伴い仰 角が高くなり，日本上空を通過したのちは仰角を下げなが ら南下していく，仰角が 90 度近くを示すことから，この 軌道配置では準天頂衛星が東京の直上を通過することがわ かる. 衛星の周回周期は静止衛星と同じく約 24 時間であっ て，地上からみて同じ衛星配置が 4 分ずつ時間を早めなが ら毎日繰り返される。

システム仰角は図中の太線のように変化する．24時間に わたる最低システム仰角は破線が示しており，この場合は 80.3 度であった.

故障等のため 1 機の衛星が停止した場合については第 1 図でいずれか一つの衛星を除いて考えればよく，最低シス テム仰角は点線のとおり 54.3 度に低下する。代表的な 3 地 点について，1機の衛星が停止した場合の最低システム仰 
角を求めた結果を第 2 表に示す。当然のことながら衛星数 が少ないほうが影響が大きく，3衛星の構成では，東京で 30 度以下，稚内では 20 度以下まで仰角が低下する。また, 高緯度地方で影響が大きくなる傾向がある一方, 4 衛星以 上があれば南西諸島では大きな影響はないことがわかる。

\section{4. 隣接衛星の再配置による性能回復}

4.1 衛星の再配置 準天頂衛星システムは複数の衛星 から構成されているのであるから，ある衛星が停止した場 合には，隣接した位置に配置されている衛星を停止した衛 星に近づくように移動させることによりシステム性能を回 復させることが考えられる。このような措置は, GPS 等の 既存衛星測位システムでも実際に行われていることである.

ただし，準天頂衛星システムについては各衛星の軌道面 が異なることに注意が必要である。すなわち, 地上軌跡が 同一の 8 の字となるよう $n$ 機の衛星を均等に配置するに は, エポック時刻における平均近点角（近地点からの移動 量を角度で表した值）を

$$
M_{0, i}=M_{0}+\frac{360}{n}(i-1)
$$

としたとき, 昇交点赤経（慣性系における昇交点の春分点 方向に対する経度）を

$$
\Omega_{0, i}=\Omega_{0}-\frac{360}{n}(i-1)
$$

のように選ぶ必要がある。ここで $i$ は衛星の番号で, $1 \sim n$ の整数である.

衛星の軌道を変更して再配置を行うことを考える．第 2 図はある準天頂衛星 SV1 の軌道を表しており, 実線が地上 軌跡, 白丸はある時点における衛星の位置である。これに 対して, 平均近点角を 30 度進めたうえで昇交点赤経を 30 度戻すと衛星はSV1a の位置に移動し, 同一の地上軌跡を 維持しながら位相だけを 30 度進めることができる。一方, 昇交点赤経を変えずに平均近点角だけを 30 度進めた場合は $\mathrm{SV} 1 \mathrm{~b}$ のようになり, 衛星の南北方向の移動の様子は SV1a と同様であるが, 地上軌跡が東方に 30 度移動してしまう のである.

昇交点赤経の違いは軌道面が異なることを意味する。一

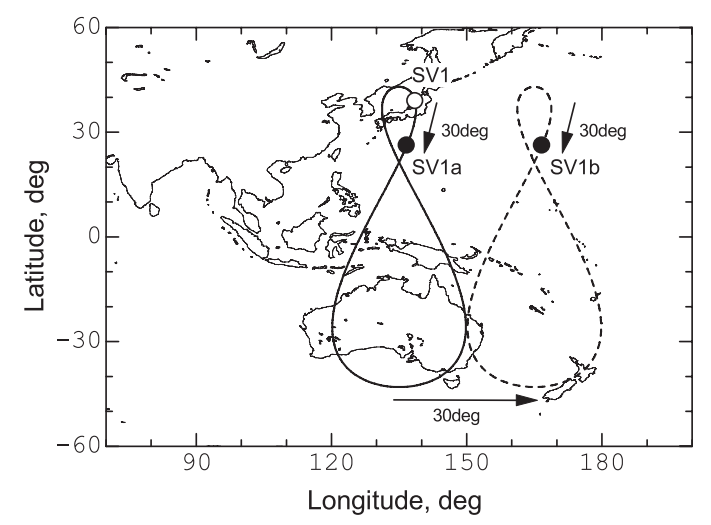

第 2 図 衛星の再配置
般に人工衛星の軌道面を変更するには多量の燃料消費を必 要とし, 衛星の寿命を大きく縮めることになる. GPS 等の 衛星測位システムで衛星の配置を変更する場合も, 同一軌 道面内で実施するのが普通である。

\section{2 隣接衛星の再配置による効果（軌道面制御あり）}

準天頂衛星システムにおいていずれかの衛星が停止した場 合について, 停止した衛星に隣接して配置されている 2 機の 衛星に対して軌道制御を実施して再配置することを考える.

まず，地上軌跡が同一の 8 の字を維持するように，平均 近点角と昇交点赤経の両方を変更することを考える（第 2 図の SV1a が対応する). 昇交点赤経が変わるのであるか ら, この再配置は軌道面の変更を伴うこととなる.

再配置のための移動量 $\Delta$ は, 平均近点角が停止衛星か ら離れる方向を正とする。すなわち, SV $i$ 衛星が停止した とき, $\mathrm{SV} i-1$ 衛星及び $\mathrm{SV} i+1$ 衛星の（エポック時刻 における）平均近点角をそれぞれ

$$
\begin{aligned}
& M_{0, i-1}^{\prime}=M_{0, i-1}-\Delta \\
& M_{0, i+1}^{\prime}=M_{0, i+1}+\Delta
\end{aligned}
$$

に，昇交点赤経については

$$
\begin{aligned}
& \Omega_{0, i-1}^{\prime}=\Omega_{0, i-1}+\Delta \\
& \Omega_{0, i+1}^{\prime}=\Omega_{0, i+1}-\Delta
\end{aligned}
$$

に変更する。

最低システム仰角の計算結果を第 3 図に示す。図中の白 抜き記号は衛星停止前, 実線は 1 衛星が停止した場合の各 地における最低システム仰角を表しており, 横軸は移動量 $\Delta$ に対応する。 また, 参考のために各地における静止衛星 (東経 135 度) の仰角を破線で表示してある。

4 衛星及び 5 衛星構成においては那覇では改善がみられ ないが, それ以外については 30 度以下の移動量ならほぼ 線形に最低システム仰角が改善し, 最大では 20 度以上の 改善が得られることがわかる. 30 度を超えて移動を行うと 逆に性能が低下する。

この理由を説明するために, たとえば 3 衛星による構成 を考える。再配置により各衛星の位相関係は第 4 図のよう に変化し，移動量を 30 度とした場合に 2 衛星が均等に配 置された状態となる。このため, 最低システム仰角を最大 とする移動量は 30 度となるのである. 同様に, 4 衛星構成 では同じく 30 度, 5 衛星構成では 24 度の移動量としたと きに最低システム仰角が最大值を示すこととなる。

移動量 $\Delta=-20$ 度とした場合の再配置による軌道の変 化を第 5 図に示す。これは 4 衛星構成において SV4 衛星 が停止した場合の例であり, 平均近点角及び昇交点赤経の 変更により SV1 及び SV3 衛星の位相が前後する様子がわ かる。

なお, 第 3 図の結果は停止衛星に隣接する 2 機の衛星の 両方を移動させることとして得たものであるが, いずれか 一方の再配置だけで最低システム仰角を改善することも可 能である。サービスエリア全体の性能を維持する観点から 


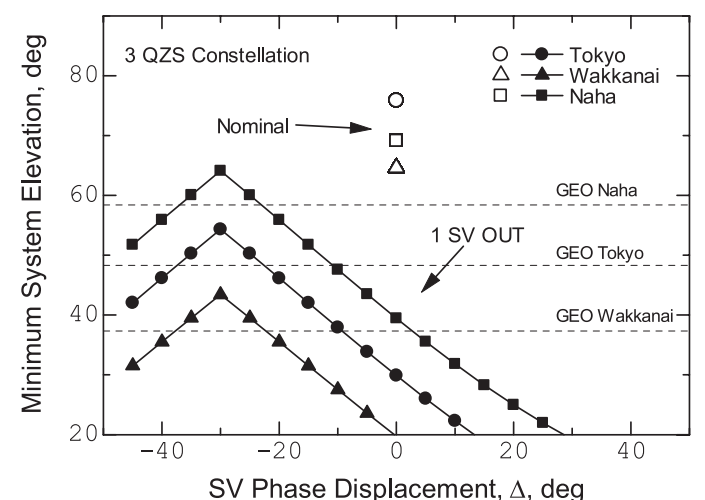

(a) 3 衛星構成

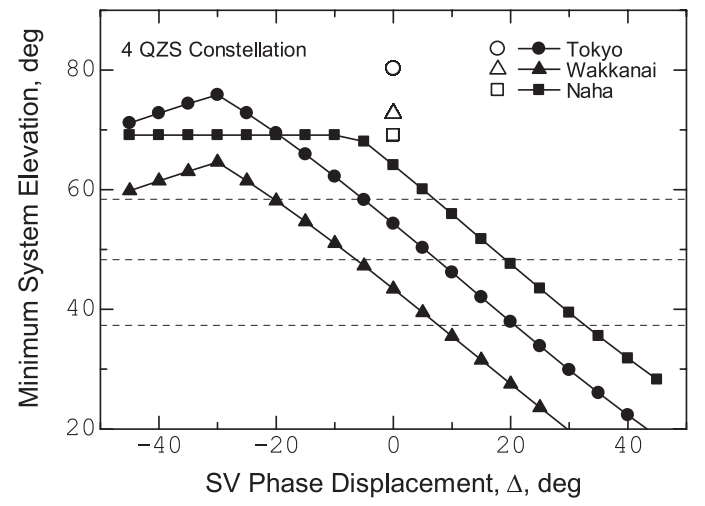

(b) 4 衛星構成

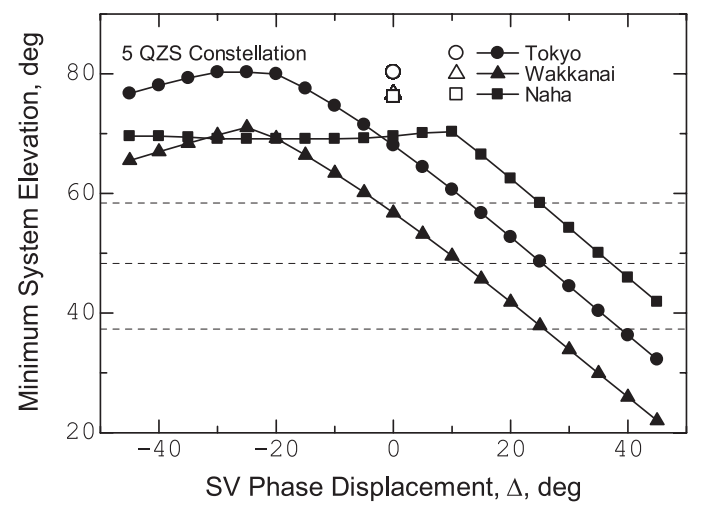

(c) 5 衛星構成

第 3 図隣接衛星を再配置した場合の最低システム仰角（軌道面制御 あり)

は稚内における改善効果を重視する必要があることから， ユーザ位置を稚内として，再配置する衛星を 2 機あるいは いずれか 1 機とした場合の性能改善効果の比較を第 6 図に 示す.いずれの構成についても 2 機の衛星を両方とも再配 置することが有効であるが, どちらか一方しか移動させな いこととしても半分程度の効果が得られる. また, 再配置 の対象とする衛星の組合せにかかわらず, 移動量 $\Delta<0$, すなわち停止した衛星に平均近点角を近づける方向に移動 させるべきであることがわかる。

4.3 隣接衛星の再配置による効果（軌道面制御なし） 次に，現実には軌道面制御には多量の燃料消費が必要とな ることを踏まえ, 軌道面制御を行わずにシステム性能の回 復を図ることを考える。すなわち，停止した衛星に隣接し

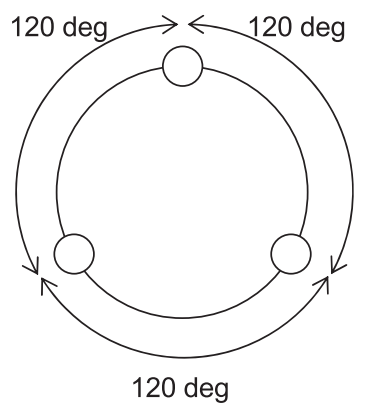

(a) 再配置前 (b) 再配置後

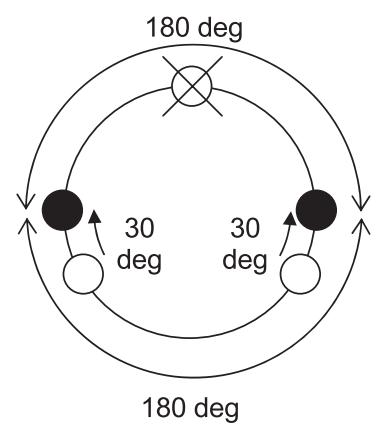

第 4 図 再配置による位相の変化

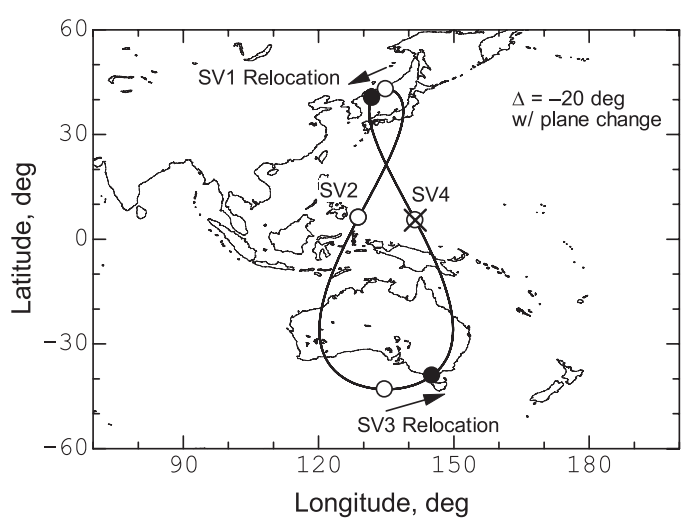

第 5 図 再配置された衛星の軌道（軌道面制御あり）

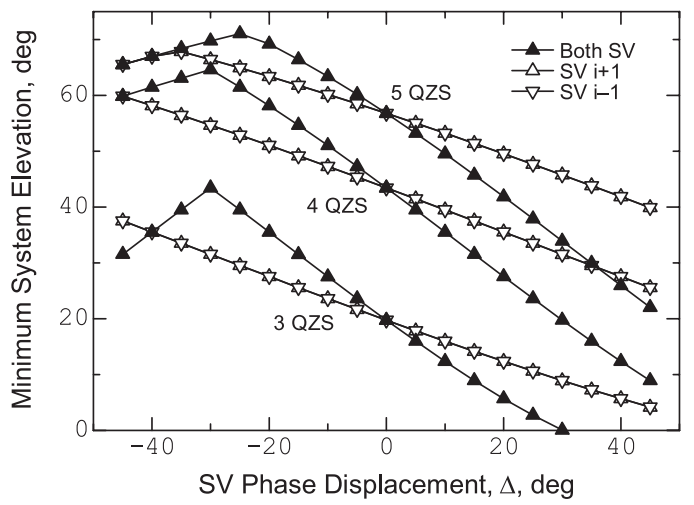

第 6 図 再配置する衛星の組合せを変えた場合（軌道面変更あり）

て配置されている 2 機の衛星に対して, 平均近点角のみを 変更する. 衛星の軌道は第 2 図の SV1bのように変化し, 地上軌跡はもとと同一の 8 の字とはならない.

具体的には, SV $i$ 衛星が停止したとき, SV $i-1$ 衛星及 び SV $i+1$ 衛星の平均近点角をそれぞれ式 (3) 及び (4)の とおり変更する. 昇交点赤経は変更しない（式 (5) 及び (6) は適用しない)。この方法による場合の最低システム仰角の 計算結果を第 7 図に示す. 3〜 衛星のいずれの構成におい ても稚内でもっとも高い改善効果が得られている. 3 衛星 及び 4 衛星構成の場合は, 2 機の衛星をそれぞれ 25 度程度 移動させることで最低システム仰角を 10 度程度高める効 果がある．5 衛星構成の場合はそこまで顕著な効果はみら れないが， 6 度以上の改善は期待できる。第 2 表によれば 


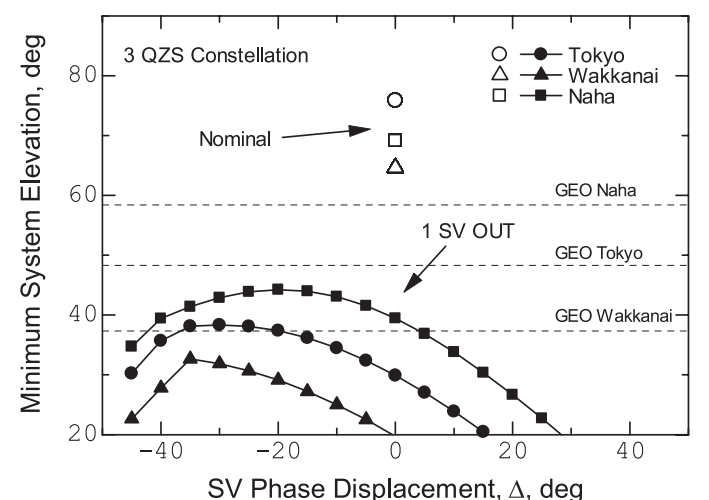

(a) 3 衛星構成

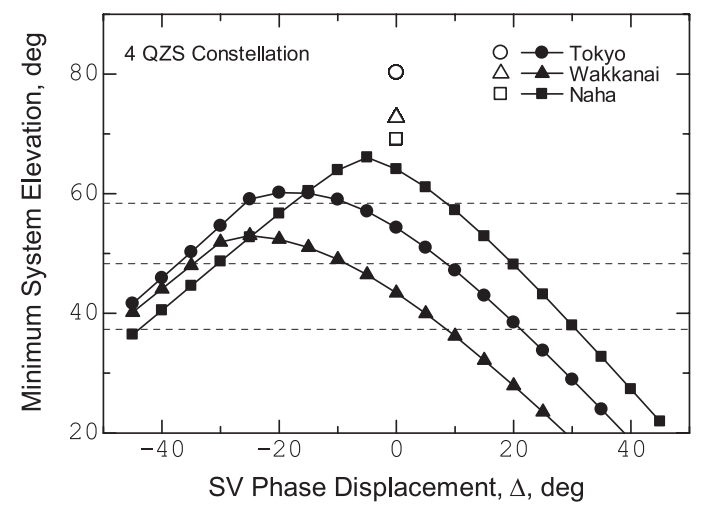

(b) 4 衛星構成

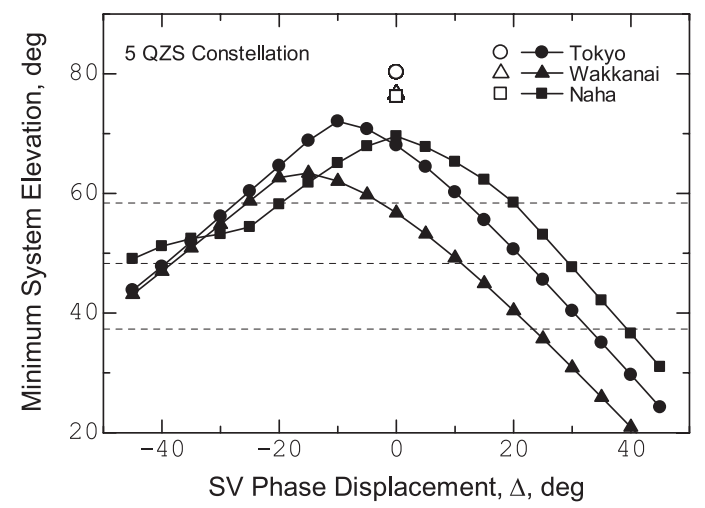

(c) 5 衛星構成

第 7 図 隣接衛星を再配置した場合の最低システム仰角（軌道面制御 なし)

衛星の停止による影響を受けやすいのは高緯度地方であっ たから，これは望ましい性質といえる。一方，那覇におい ては 5 機以上の構成では再配置による効果はみられない.

第 5 図と同様に，軌道面制御を行わないこととしたとき， 移動量 $\Delta=-20$ 度とした場合の再配置による軌道の変化 を第 8 図に示す。平均近点角の変更により, SV1 及び SV3 衛星の地上軌跡が東西に移動する様子がわかる.

再配置する衛星を 2 機あるいはいずれか 1 機とした場合 について, 稚内における性能改善効果を比較した結果を第 9 図に示す。いずれの構成についてもやはり 2 機の衛星の 両方を再配置することが有効であるが，どちらか一方しか 移動させないのであれば SV $i-1$ 衛星（昇交点赤経の大き なほうの衛星）を対象とするほうが有利である.

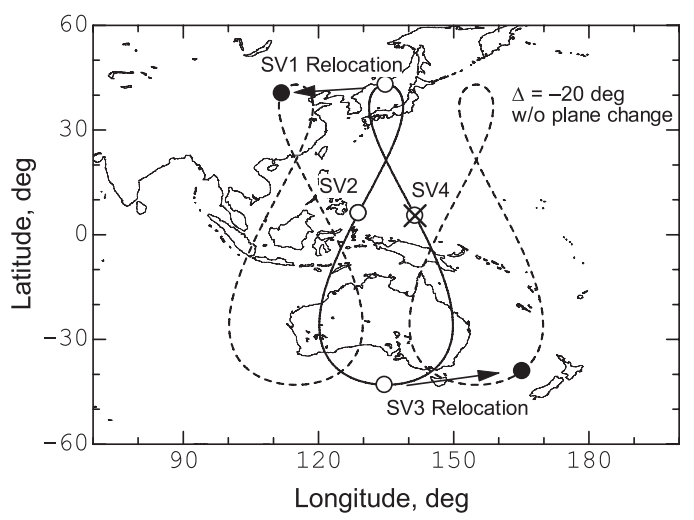

第 8 図再配置された衛星の軌道（軌道面制御なし）

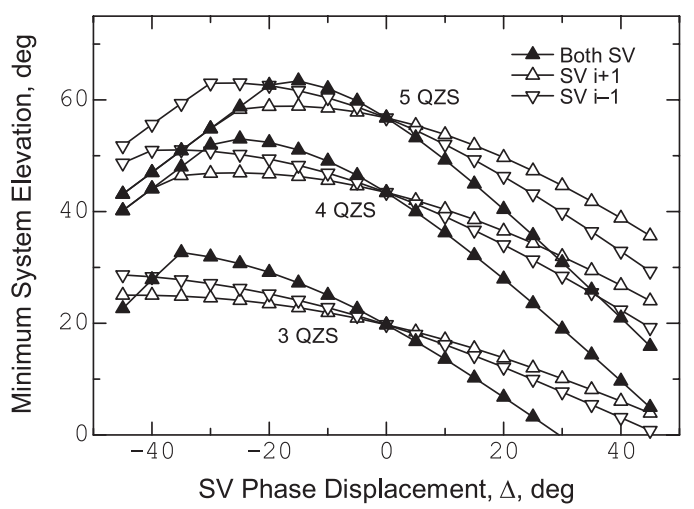

第 9 図 再配置する衛星の組合せを変えた場合（軌道面変更なし）

\section{5. 結言}

準天頂衛星システムを対象として, 故障等による衛星停 止時について停止衛星に隣接する衛星を再配置することで システム性能を回復させる手法を検討した。準天頂衛星シ ステムの利用の観点から, 利用可能な複数の衛星のうちの もっとも高い仰角をシステム仰角と定義してその最低值に よる性能評価を行ったところ，衛星停止時に大きな影響を 受けるのは高緯度地域のユーザであることがわかった，停 止衛星に隣接する 2 機の衛星を再配置することにより最低 システム仰角を回復することは可能であり, 高緯度地域の ユーザに対しては，軌道面制御を伴う場合は 20 度以上，軌 道面制御を行わない場合でも 6 10 度程度の改善を期待で きる、また，移動対象を隣接する 2 機の衛星のうちのいず れか一方のみとする場合は, 昇交点赤経の大きなほうの衛 星を移動すべきである。

参 考 文 献

1）沢辺幹夫: 準天頂衛星を利用した高精度測位実験システムプロジェ クトの概要, GPS/GNSS シンポジウム 2004 テキスト， 2004, pp. $77-84$.

2) 沢辺幹夫，吉冨 進，小暮 聡，鶴田尚史，岸本統久：準天頂高 精度測位実験の概要について, 第 50 回宇宙科学技術連合講演会, 2006, pp. $743-748$.

3) 野田浩幸: 準天頂衛星システム技術実証: 準天頂高精度測位実験, GPS/GNSS シンポジウム 2011 テキスト, 2011, pp. 27-32.

4) 田中正人：8の字衛星の利用技術, 日本航海学会誌, 149 (2001), pp. 83-90. 
5) Parkinson, B.: Introduction and Heritage of NAVSTAR, the Global Positioning System, Global Positioning System: Theory and Applications, Vol. I, Parkinson, B. and Spilker, J., eds., AIAA, Washington, DC, 1996, pp. 3-28.

6) Zhang, K., Liu, J. and Yang, Y., eds.: Chinese Beidou and the Next Generation GNSS, J. Navigation, 64 (2011), pp. $\mathrm{S} 1-\mathrm{S} 232$.

7) Majithiya, P., Khatri, K. and Hota, J.: Indian Regional Navigation Satellite System, Inside GNSS, 6 (2011), pp. 40-46.

8) Ganeshan, A. S.: On Indian Satellite Based Navigation Systems and Implementation Status, ICG/6, UNOOSA, Tokyo,
2011

9) International Standards and Recommended Practices, Annex 10 to the Convention on International Civil Aviation (Aeronautical Telecommunications), 6th ed., Vol. I, ICAO, Montreal, 2006.

10）麻生貴広：MSAS の運用状況と地殼変動への対応, GPS/GNSS シンポジウム 2011 テキスト, 2011, pp. 21-26.

11）坂井丈泰：広域補強システム MSAS/SBAS, GPS ハンドブック, 朝倉書店，東京，2010, pp. 222-235.

12) Interface Specification for QZSS (IS-QZSS), Version 1.4, JAXA, 2012, http://qz-vision.jaxa.jp/USE/is-qzss/ 